\title{
Visualized Analysis of the Research on Ideological and Political Education Policy
}

\author{
Guo Peng, Su Chang, Feng Yue \\ Dept. of Marxism, Xi'an University of Science and Technology \\ Xi'an, China \\ e-mail: xianguopeng@qq.com
}

\begin{abstract}
The research on ideology and political education enjoys dual attributes of both ideology and practice, guiding and leading the development of ideology education and ideological and political work of China's colleges. As an emerging interdisciplinary field, it's of greatly theoretical and practical significance to start the research of the transitions and changes of ideology education from the political perspective. In the recent years, academia has paid increasing attention to the ideology education, which scholars carry out their study on environmentalism, systematology and policy alternation. In the light of scientific data-exploration tools and visualized maps, the annual distribution, the co-occurrence of key words, and the evolution of the hot spots of these documents are analyzed and summarized visually by scientific research institutions and partners, which can reveal more clearly and directly the research process, status and features, and draw inspiration on research methods, contents, and direction to the future.
\end{abstract}

Keywords-Ideological; Political Education Policy; Mapping Knowledge Domain; Visualized Analysis

\section{INTRODUCTION}

Since 1993, the academic attention of "ideological and political education policy" has grown out of nothing, and the study of the policy of ideological and political education has received increasing attention in academic circles. In recent years, the study of ideological and political education policy has focused on environmentalism, systematology and policy alternation. It is necessary for us to analyses it by using the methodology of visualized analysis in Cite Space III, research the literature that is related to the policy of ideological and political education in CNKI, as well as learn the information of research process, leaders and its forefront, which are beneficial to the development of its field in the future.

\section{DATA ACQUISITION AND RESEARCH METHOD}

Based on the CNKI database of periodical literature, dissertation, we research subject words with" ideological and political education policy" and the "Ideological and Political Education \&Policy". The time span for all years. A total of 150 documentaries are recorded on September 9, 2017. Get rid of that literature with weak correlation, 103 are left. Each record contains authors, institutions, title, abstract, keywords, cited journals and the year of publication, but does not include the information of reference. Draw the mapping of science with Cite Space III which is developed by Doctor Chen Chaomei of Drexel University, shows the trend of a subject or a field in a certain period forms the progress in some front fields.

\section{ANALYSES OF RESULTS}

\section{A. Literature Annual Distribution}

Literature analysis of annual distribution of a field is beneficial for understanding the scholar's research progress and research focus in this field from the dimension of time, according to the literature, statistical Chinese research literature about ideological and political education policy of dividing the year as is shown in Figure 1.

Study on the ideological and political education policy in China was started in 1993, until 2006 gradually formed the scale. The first article is a discussion about "function and feature about ideological and political education of policy". From 1993 to 2005, the number of literature is less, the total does not exceed a digit, there are few scholars pay attention 
to the field. Scholars pay more and more attention to ideological and political education policy, the number of literature began to increase from 2006, and reached the peak in 2014(20 pieces), more than $94 \%$ of the literature is published in 2016,the reason needs further study. The quantity of literature search in 2017 is less because it was not covered the whole year.

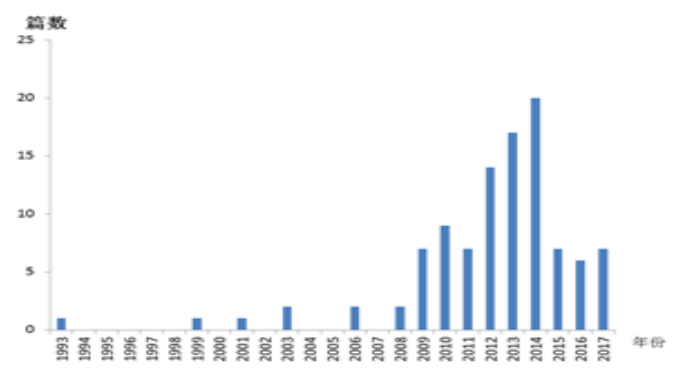

Figure 1. The annual published paper amount of the research on Ideological and Political Education Policy

\section{B. The Analysis of key words co-occurrence and research focus evolution}

Mapping knowledge domain about key words co-occurrence with Cite Space III is shown in table 2, you can see China scholars research focus on the field which is ideological and political education policy. It can be seen that the largest node is "Ideological and political education", means that the frequency is the largest. The connection line between key words refers to these two words appear in the same literature, the thickness of the lines is related with the occurrence number. In addition, it can be seen that scholars focus on the high frequency words such as" policy environment", "policy implementation" and "policy alteration" for study. The key words that will appear frequency greater than 4 are listed in the frequency order as is shown in table 1 .

It can be seen from table 1 that the highest centrality is "Ideological and Political Education", and "Policy Environment", "Education Policy", and "Policy Changes" followed. This phenomenon shows that in recent years we start the study of the ideological and political education policy around these important points.
TABLE I. FREQUENCY GREATER THAN 4 KEYWORDS

\begin{tabular}{|c|c|c|c|c|c|}
\hline Beywords & $\begin{array}{l}\text { The } \\
\text { frequency } \\
\text { of }\end{array}$ & Center ${ }^{1)}$ & Keyrords & $\begin{array}{l}\text { The } \\
\text { frequency } \\
\text { of }\end{array}$ & $\begin{array}{c}\text { of } \\
\text { Central }\end{array}$ \\
\hline $\begin{array}{l}\text { Ibeological and } \\
\text { political education }\end{array}$ & 64 & 0.91 & $\begin{array}{l}\text { Ideological and } \\
\text { political education in } \\
\text { collezes and } \\
\text { universities }\end{array}$ & 5 & 0.09 \\
\hline Policy environgent & 9 & 0.15 & Education policy & 4 & 0.13 \\
\hline The policy change & 7 & 0.09 & $\begin{array}{l}\text { Ideological and } \\
\text { political }\end{array}$ & 4 & 0.07 \\
\hline Policy impleantation & 7 & 0.01 & $\begin{array}{l}\text { Path depeadence } \\
\text { Ideolorical and }\end{array}$ & 4 & 0.02 \\
\hline Discipline policy & 6 & 0.05 & $\begin{array}{l}\text { political educatica of } \\
\text { colleze studeats } \\
\text { Ideolorical and }\end{array}$ & 4 & 0.09 \\
\hline College studeats & 6 & 0.1 & $\begin{array}{l}\text { political education } \\
\text { policy }\end{array}$ & & 0.04 \\
\hline $\begin{array}{l}\text { Ibeological and } \\
\text { polititical education } \\
\text { policy }\end{array}$ & 5 & 0.02 & & & \\
\hline
\end{tabular}

The analysis map of the co-occurrence of key words shows in the form of Time zone, we can understand in the study front and the development trend of Ideological and Political Education in China more clearly. With times goes by, key words with "Ideological and Political Education" as the beginning, the study content is also changing. "policy implementation" ,"content analysis", "text analysis", "policy optimization", "model analysis", "the CPC Central Committee document NO. sixteen", "central policy change", "environment theory" have become the front direction of study in recent years, the methods of research policy, the establishment of policy environment and the implementation of policy have become the new hot spot in the research of ideological and political education policy.

Find the Frequency that is greater than 2 keywords that appeared for the first year and collate them out, as is shown in table 2, from 2009 to 2011, the ideological and political education research focuses on aspects of policy, policy changes, $\mathrm{Xu}$ Yanguo proposes theory of ideological and political education environment, the principles on the environment, factors such as a series of discussion; He to diversify, such as key words for "National Collagen Dan combed the history of ideological and political education policy changes, policy changes, which were divided into 5 stages. In recent years, scholars have begue", "youth" and the research of ideological and political education policy has been studied in a group; the key word "historical institutionalism", "textual analysis" studies of new research methods into the study of ideological and political education policy. In the research field of ideological and political education policy, scholars in our country has achieved 
certain results about "policy changes", "policy environment", they are researching ideological and political education policy in more deeply field with new technology and new ideas, which will promote this field developing schedule, the subject development of ideological and political education, and provide theoretical basis for make scientific policy, implement effectively, evaluate reasonably and optimize constantly. The present research field is simple, the way is single, research and grasp the relationship between subject, object, environment, making, implementation, evolution and quantity assurance in ideological and political education policy without many angles, and it does not form the result that the whole is better than the addition of all parts, the research of this aspect needs to be further strengthened.

TABLE II. HIGH FREQUENCY WORDS FIRST YEAR

\begin{tabular}{|c|c|c|c|c|c|c|c|}
\hline Sorting & Author & $\begin{array}{c}\text { Issued } \\
\text { quantity }\end{array}$ & $\begin{array}{l}\text { The first } \\
\text { article } \\
\text { was } \\
\text { published } \\
\text { the year }\end{array}$ & Sorting & Author & $\begin{array}{c}\text { Issued } \\
\text { quantity }\end{array}$ & $\begin{array}{l}\text { The first } \\
\text { article } \\
\text { was } \\
\text { published } \\
\text { the year }\end{array}$ \\
\hline 1 & $\begin{array}{c}\mathrm{Xu} \\
\text { Yanguo }\end{array}$ & 13 & 2010 & 5 & $\begin{array}{c}\text { Qiu } \\
\text { Qizhao }\end{array}$ & 4 & 2013 \\
\hline 2 & $\begin{array}{l}\text { Song } \\
\text { Juncheng }\end{array}$ & 7 & 2011 & 6 & $\begin{array}{c}\text { Yang } \\
\text { Liansheng }\end{array}$ & 3 & 2011 \\
\hline 3 & Han Dan & 6 & 2010 & 7 & $\underset{\text { Jianiun }}{\mathrm{Xu}}$ & 3 & 2010 \\
\hline 4 & $\begin{array}{c}\text { Huang } \\
\text { Rongsheng }\end{array}$ & 4 & 2012 & & & & \\
\hline
\end{tabular}

\section{Visual Analysis of scientific Research Institution}

In order to understand the relationship between the contributions of relevant organizations in these field and partners, to make scientific analysis of institutions, as is shown in table 3, a total of 77 nodes in the graph (i.e. research institutions) and a total of 15 lines, it explains the research in the field of Ideological and political education policy, the cooperation between institutions and organizations is not much., and it have not formed the clustering phenomenon. The cooperation between Dalian University of Technology (Marx Institute of Dalian University of Technology) and the Eastern Liaoning University (ideological Department of Eastern Liaoning University, Eastern Liaoning University of Ideological and political education and Cultural Policy Research Canter)is the most, up to 3 lines. The results will be issued more than 2 institutions according to the Issued amount from more to less orderly, as shown in Table 3, the research of the ideological and political education policy of the Tsinghua University and the Huazhong University of Science and Technology at the forefront. The Marx Institute (ideological Department) is the main force of papers, research institutions have issued a document in statistics, but no enterprises. Enterprises especially state-owned enterprises adhere to Policy guidance to strengthen the ideological and political education is the base for enterprise to realize sustainable development. Enterprises in the implementation of the policy should also strengthen the research on the ideological and political education policy, to find the theoretical source for the practice.

TABLE III. INSTITUTIONAL WHICH HAD PUBLISHEd MORE THAN 2

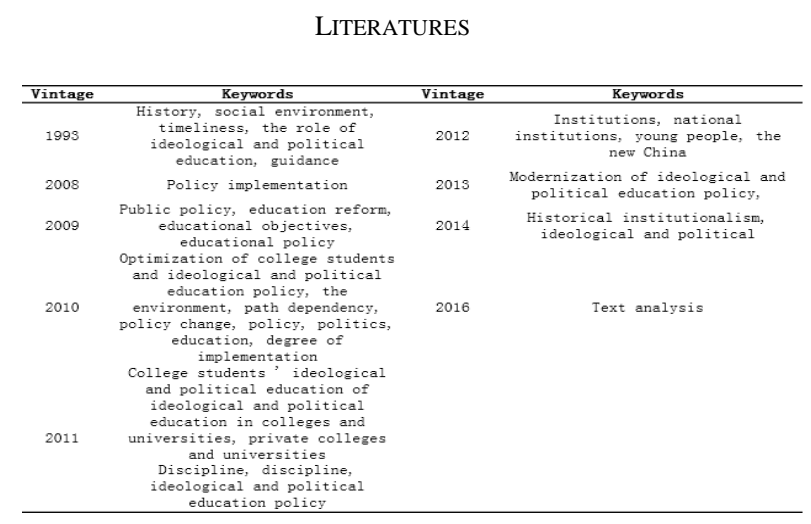

D. Co-operators analysis

Using Cite Space III to generate the map domain of authors co-occurrence was shown in the table, there are 93 network nodes and 30 lines in the table, node larger represent corresponding scholars has published more articles, reveals that $\mathrm{Xu}$ Yanguo has most published ,his paper amount is up to 13 , and the major of research direction is the environment of ideological and political education policy; next one is Song Juncheng, his major of research direction is the part of ideological and political education subject in ideological and political education policy; the number three is Han Dan who mainly research policy changes. Huang Rongsheng, QiuQIzhao, YangLiansheng and Xu Jianjun followed closely, arranging more than 3 paper of scholars and the first published article time are as shown in Table 4, in the field of research ideological and political education policy, scholars in our country less cooperation ,mostly 
published article by themselves, $\mathrm{Xu}$ Yanhuo and $\mathrm{Xu}$ Jianjun has cooperated 3 literatures.

TABLE IV. AUthors WHO HAD PUBLISHED MORE THAN 3 Literatures

\begin{tabular}{|c|c|c|c|c|c|}
\hline Agency & $\begin{array}{c}\text { Issued } \\
\text { quantity }\end{array}$ & $\begin{array}{l}\text { First year } \\
\text { of } \\
\text { publication }\end{array}$ & Agency & $\begin{array}{c}\text { Issued } \\
\text { quantity }\end{array}$ & $\begin{array}{l}\text { First yeax } \\
\text { of } \\
\text { publication }\end{array}$ \\
\hline $\begin{array}{l}\text { langhua University } \\
\text { center for study of } \\
\text { moral eduction in } \\
\text { colleges and } \\
\text { universities }\end{array}$ & 6 & 2012 & $\begin{array}{l}\text { School of political } \\
\text { sciences }\end{array}$ & 2 & 2010 \\
\hline $\begin{array}{l}\text { Huazhong University } \\
\text { of science and } \\
\text { school of Marxism }\end{array}$ & 4 & 2010 & $\begin{array}{l}\text { Department of } \\
\text { Eastern Lianining } \\
\text { University's } \\
\text { ideological and } \\
\text { political }\end{array}$ & 2 & 2011 \\
\hline $\begin{array}{l}\text { Tsinghua University } \\
\text { School of Marxism }\end{array}$ & 4 & 2012 & $\begin{array}{l}\text { Guilin University of } \\
\text { electronic technology } \\
\text { Departmenti of } \\
\text { political } \\
\text { Faculty of }\end{array}$ & 2 & 2013 \\
\hline $\begin{array}{l}\text { Eastern Liaoning } \\
\text { University }\end{array}$ & 3 & 2014 & $\begin{array}{l}\text { Humanitics and } \\
\text { social sciences, } \\
\text { Dalian University }\end{array}$ & 2 & 2011 \\
\hline Uestc & 2 & & Southwest University & 2 & \\
\hline
\end{tabular}

IV. CONCLUSIONS

In this paper, it uses information visualization software Cite Space III to make the analysis of mapping science domain with has collected related article about the study of ideological and political education policy which from key words, publish institutions and authors, we draw the following conclusions:

Scholars in our country about ideological and political education policy research literature are not much before 2006, literature grows annually from 2006 to 2014, and it reached the peak in 2014. This phenomenon reflects the value of leading edge research in the field has been discovered. Xu Yanguo, Song Junchen, Han Dan and other major authors doctoral dissertation topic and posting circle, their research promote literature appeared, stating that the research subjects in the field of advanced research, and the higher level, it requires a certain amount of research capacity and infrastructure in order to carry out related research. Change in policy development, in larger cycles in this field should be presented gradually. On the one hand, Literature in the early peak of volatility and change, on the other hand, it notes main author doctorate after the follow-up study also required further follow up, it also needs more attention and investment in this area.

Scholar for research of the environment of ideological and political education policy theory is mainly focused on policy changes, and so on, and the main method of text analysis. research and practice are more closely in recent years, diversification, careful, direction is the current trends in research. Policy innovations, synergetic relationship between policies, policy evaluation is rarely involved in research.

Marxism became the main subject of research in the field of colleges and research institution, University administration, enterprise ideological and political education policy research is very rare. Administration is another subject of the ideological and political education, and they are the development partners, implementation of the policy, administration agencies, such as the strengthening of ideological and political education policy research more scientific policies, improve the optimization policy, build reasonable environment and promote policy innovation.

Prolific author $\mathrm{Xu}$ Yanguo, Song Juncheng, Han Dan, and less cooperation between scholars. In the days of five large development philosophy deeply remembered inside people, open academic, knowledge sharing have become the trend of the times, building a good network of cooperation between scholars can greatly promote the ideological and political education policy study pace.

\section{ACKNOWLEDGMENT}

*Supported by philosophy and social science of Xi'an University of Science and Technology(2017SZ01)

\section{REFERENCES}

[1] Gu Zhongp, "The function and characteristics of the ideological and political education of the policy", in Harbin: Theoretical Investigation, Jan.1993. pp.43-53(In Chinese).

[2] Xu Yang, "On the Ideological and Political Education Policy Environment, "in Doctoral dissertations ,Changsha: Central South University, 2010. pp.8-12 (In Chinese).

[3] Zhang feng and Han dan, "On the dynamic mechanism of the policy changes of Ideological and political education in colleges and Universities", in Changchun: Journal of Northeast Normal University (PHILOSOPHY AND SOCIAL SCIENCE EDITION), Mar.2013(In Chinese).

[4] Gao shan, "A review of the essence of Ideological and political education", in. Wuhan:School Party Building and Ideological Education, Oct.2010.pp58-61 (In Chinese). 